\title{
Study on Kinetic and Optimization of Continuous Advanced Oxidative Decolorization of Brilliant Reactive Red Dye
}

\author{
Forqan M. Hameed and Khalid M. Mousa
}

Chemical Engineering Department, Al-Nahrain University, Iraq

\begin{abstract}
The azo dye brilliant reactive red K-2BP $(\lambda \max =534 \mathrm{~nm})$ is widely used for coloring textiles because of its low-cost and tolerance fastness properties. Wastewaters treatment that contains the dye by conventional ways is usually inadequate due to its resistance to biological and chemical degradation. During this study, the continuous reactor of an advanced oxidation method supported the use of $\mathrm{H}_{2} \mathrm{O}_{2} /$ sunlight, $\mathrm{H}_{2} \mathrm{O}_{2} / \mathrm{UV}, \mathrm{H}_{2} \mathrm{O}_{2} / \mathrm{TiO}_{2} /$ sunlight, and $\mathrm{H}_{2} \mathrm{O}_{2} / \mathrm{TiO}_{2} / \mathrm{UV}$ for decolorization of brilliant reactive red dye from the effluent. The existence of an optimum $\mathrm{pH}, \mathrm{H}_{2} \mathrm{O}_{2}$ concentration, $\mathrm{TiO}_{2}$ concentration, and dye concentration was taken from the batch reactor experiments. The best conditions were $\mathrm{pH}=3, \mathrm{H}_{2} \mathrm{O}_{2}$ dosage $=500 \mathrm{ppm}, \mathrm{TiO}_{2}=100 \mathrm{ppm}$ and dye concentration=15 ppm. Under the most effective conditions, complete removal of the dye solution was achieved with different flow rates $(10,30,60) \mathrm{ml} / \mathrm{min}$. At flow rate of $10 \mathrm{ml} / \mathrm{min}$, the percentage of decolorization were $(80.47 \%, 84.65 \%, 89.42 \%, 77.5 \%)$ and at $60 \mathrm{~mL} / \mathrm{min}(65.19 \%, 68.26 \%$, $70.01 \%, 56.8 \%$ ) for $\mathrm{H}_{2} \mathrm{O}_{2}$ /sunlight, $\mathrm{H}_{2} \mathrm{O}_{2} / \mathrm{UV}, \mathrm{H}_{2} \mathrm{O}_{2} / \mathrm{TiO}_{2} /$ sunlight and $\mathrm{H}_{2} \mathrm{O}_{2} / \mathrm{TiO}_{2} / \mathrm{UV}$ respectively. Results of degradation information showed that the decolorization method was pseudo-first-order kinetics.
\end{abstract}

Keywords: Reactive Red, Photodegradation, advanced oxidation processes (AOP), Wastewater, Sunlight

Received on 08/10/2018, Accepted on 17/12/2018, published on 30/03/2019

https://doi.org/10.31699/IJCPE.2019.1.2

\section{1- Introduction}

Wastewater produced from the textile industry typically contains high concentrations of organic, inorganic materials, high $\mathrm{COD}$, high $\mathrm{pH}$ and strong apparent color [1]. Dyes from coloring processes are the primary supply of color textile wastewater and it may cause serious environmental issues [2].

There are different types of treatment such as physicalchemical treatment included [coagulation-flocculation, adsorption on activated carbon and reverse osmosis] and biological treatment are used for removal toxic substance from wastewater. Biological treatment isn't effective enough to remove dyes from effluent while physicalchemical treatment is not strong enough to decolor the dye so it generated a sludge and adsorbent regeneration are the principal weaknesses of those methods [3]. advanced oxidation processes (AOPs), that are considered a chemical treatment of wastewater and it is the most effective process for the removal of the organic pollutants [4]. AOPs are based on the generation of hydroxyl radical $\left(\mathrm{OH}^{*}\right)$ that are capable of degrading the organic pollutants to carbon dioxide, water, and inorganic materials [5].

Various of AOPs include chlorination, ozonation, Fenton, photo-Fenton, photo-catalytic and wet-air oxidation [6] $\mathrm{H}_{2} \mathrm{O}_{2} / \mathrm{UV}$ process is one of the advanced oxidation technique, hydrogen peroxide is photolysis to generate the $\mathrm{OH}^{*}$ responsible for oxidation.
Hydroxyl radicals are attacked the organic molecules causing their destruction and mineralization. Also, another method is the photocatalyst with titanium dioxide that is a wide band gap semiconductor and it is used nearUV light of wavelength shorter than $380 \mathrm{~nm}$ or sunlight.

$\mathrm{TiO}_{2}$ particles can form a paired electron (e-) and hole $(\mathrm{h}+)$, in the conduction band and valence band when it was the absorption of the ultraviolet radiation. The positive hole is seemingly ready to oxidize a water molecule to hydroxyl radical.

The hydroxyl radical, in turn, is a powerful oxidant [7][8].

The processes of $\mathrm{H}_{2} \mathrm{O}_{2} / \mathrm{UV}, \mathrm{H}_{2} \mathrm{O}_{2} / \mathrm{TiO}_{2} / \mathrm{UV}$ treatment depends on many conditions that have an effect on the degradation of organic pollutants.

The conditions include the type and concentration of the organic materials, hydrogen peroxide concentration, $\mathrm{TiO}_{2}$ amount, light source, $\mathrm{pH}$, temperature, flow rate and reaction time [9].

The most important parameter is the dosage of $\mathrm{H}_{2} \mathrm{O}_{2}$ when its increased the formation of hydroxyl radical will be increased, therefore increasing the decolorization rate to optimal value then the $\mathrm{H}_{2} \mathrm{O}_{2}$ react with $\mathrm{OH}^{*}$ and decreased in the decolorization rate [10]. $\mathrm{pH}$ plays a major role in the photocatalytic process.

The decolorization rate of azo dyes will increase with a decrease in the $\mathrm{pH}[11]$. 
The photooxidation activity was the maximum decolorization rate under $\mathrm{pH}<6$ and it was found to decrease when $\mathrm{pH}>6$, it undergoes decomposition generating dioxygen and water lead to the less formation of $\mathrm{OH}^{*}$ [12]

In the photocatalyst, the catalyst has a control on the process, when it's increased in the quantity of it will increase in the number of active sites, that successively will cause increase the concentration of hydroxyl radical and superoxide radicals.

Also when the catalyst amount will increase higher than the optimum value, the rate of decolorization decreases because of the interception of the light by the suspension [13]. There are several studies in batch advanced oxidation, while limited studies in continuous processes conducted to remove the dye using solar energy.

Huang et al. [14] studied the parameter of adding the amount of hydrogen peroxide to remove the methyl orange from solution. The removal efficiency was increased with increase in $\mathrm{H}_{2} \mathrm{O}_{2}$ concentration. Zhiyong et al. [15] studied the addition of hydrogen peroxide with titanium dioxide Degussa P25 (0.5g/l) catalyst $(1 \mathrm{mM})$ to remove methyl orange solution under sunlight irradiation. Senthil Kumar et al. [16] reported that the increase in the concentration of $\mathrm{OH}^{*}$ will cause the reduction of the hydrogen peroxide [17]

Ali [18] studied the continuous photo-catalytic reactor using $\mathrm{TiO}_{2} / \mathrm{UV}$ process to treat wastewater solution, it showed that the rate of degradation of organic pollutants decreased with increase in the flow rate and increased with increasing the number of the UV lamp. The aim of this study is to treat the wastewater effluent from the textile factory in the north of Baghdad from the azo brilliant reactive red $\mathrm{K}-2 \mathrm{BP}$ by a continuous advanced oxidation process using $\left(\mathrm{H}_{2} \mathrm{O}_{2} / \mathrm{UV}, \mathrm{H}_{2} \mathrm{O}_{2} /\right.$ sunlight, $\mathrm{H}_{2} \mathrm{O}_{2} / \mathrm{TiO}_{2} / \mathrm{UV}$, and $\mathrm{H}_{2} \mathrm{O}_{2} / \mathrm{TiO}_{2} /$ sunlight) and compare the results.

\section{2- Experimental}

The chemicals used in this study were brilliant reactive red that is employed in textile as a waste. $\mathrm{H}_{2} \mathrm{O}_{2}(50 \%$ w/w) was obtained from Merck. $\mathrm{TiO}_{2}$ (P-25, 80t\% anatase, $20 \%$ rutile with particle size $30 \pm 5 \mathrm{~nm}$ ) was used. $\mathrm{H}_{2} \mathrm{SO}_{4}$ and $\mathrm{NaOH}$ were used to modify the $\mathrm{pH}$ of the solutions. The continuous reactor composed of 2 layers of a glass reactor $(80 \times 30 \times 1) \mathrm{cm}$. The depth between them is $4 \mathrm{~mm}$. The upper layer glass was $6 \mathrm{~mm}$ thickness and the lower layer is a reflective mirror.

The solution passes between the two layers. Two liters of effluent introduced to the unit at optimum conditions, $\mathrm{pH}=3$, dye concentration $=15 \mathrm{ppm}, \mathrm{H}_{2} \mathrm{O}_{2}=500 \mathrm{ppm}$, and $\mathrm{TiO}_{2}=100 \mathrm{ppm}$. These optimum conditions were taken from a prestudy of batch experiments.

The tests were conducted throughout the months of May and June with the temperature stable up to $35 \pm 3 \mathrm{C}^{\circ}$.
The radiation intensity was measured employing a device sort (the daystar meter) that reads $494-565 \mathrm{watt} / \mathrm{m}^{2}$ at $9 \mathrm{am}, 680-705 \mathrm{watt} / \mathrm{m}^{2}$ at $10 \mathrm{am}$ and $775-805 \mathrm{watt} / \mathrm{m}^{2}$ at $12 \mathrm{pm}$.

The processes $\left(\mathrm{H}_{2} \mathrm{O}_{2} / \mathrm{UV}, \quad \mathrm{H}_{2} \mathrm{O}_{2} /\right.$ sunlight, $\mathrm{H}_{2} \mathrm{O}_{2} / \mathrm{TiO}_{2} / \mathrm{UV}$, and $\mathrm{H}_{2} \mathrm{O}_{2} / \mathrm{TiO}_{2} /$ sunlight) for decolorization of reactive red dye from simulated solution were used. The concentration of red dye is measured by UV-Spectrophotometer at $534 \mathrm{~nm}$ maximum of absorption. Fig. 1 and Fig. 2 show the sketch and photograph of a continuous reactor. The removal efficiency (\%) was calculated using equation 1 :

Removal efficiency $(\%)=\left(\mathrm{C}_{\mathrm{o}}-\mathrm{C}\right) / \mathrm{C}_{\mathrm{o}} \mathrm{x} 100$

Where,

$\mathrm{C}_{\mathrm{o}}=$ the initial concentration of contaminants (dyes) in the samples wastewater $(\mathrm{mg} / \mathrm{l})$.

$\mathrm{C}=$ the concentration $(\mathrm{mg} / \mathrm{l})$ after treatment.

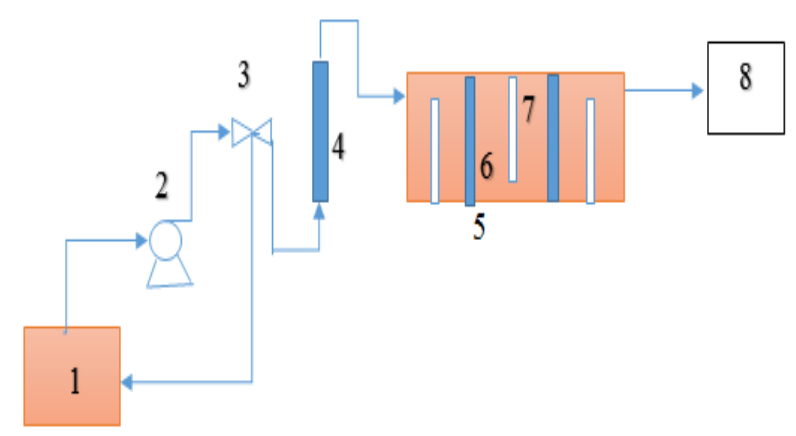

Fig. 1. Sketch of a continuous system. (1) container tank (dye solution), (2) water pump, (3) valve, (4) flow meter, (5) chamber containing the photooxidation reactor, (6) UV lamp, (7) baffle (8) container tank (produced water treated)

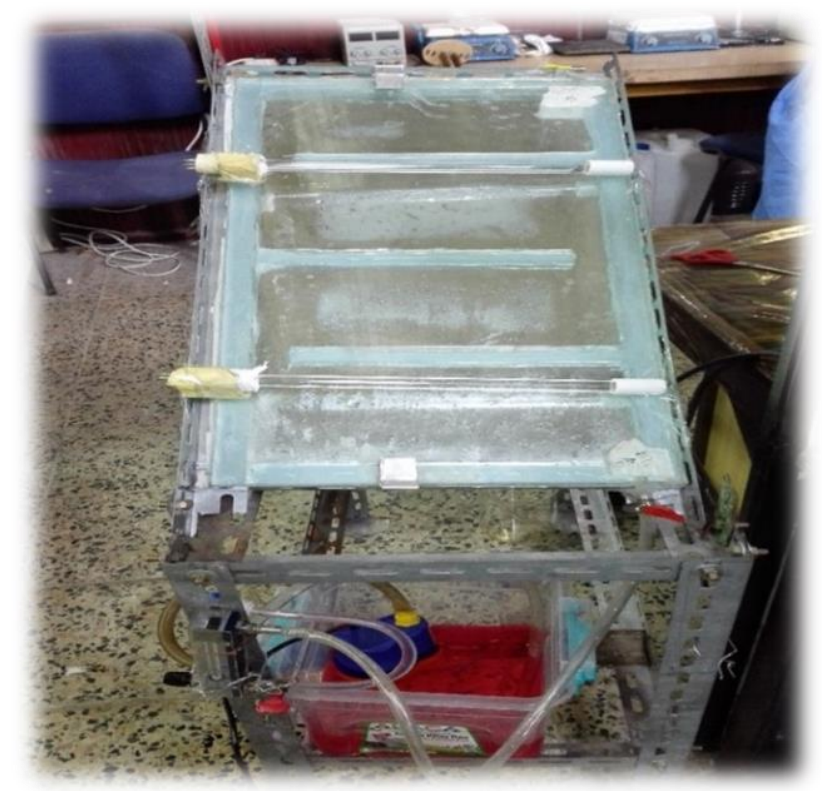

Fig. 2. Photograph of Continuous reactor 


\section{3- Kinetic Analysis}

The wastewater treatment of the textile that contains a dye is a complicated method involving several reactions. Therefore, approximate kinetics can be assumed for the removal of the dye in the effluents. The most color removal curves obey to the several investigators that are first or second order kinetics. The major color removal curves lead to the first order kinetic model [19]. The rate of kinetic for the first order reaction can be calculated from equation 2 :

$-\frac{\mathrm{dC}}{\mathrm{it}}=\mathrm{KC}$

\section{Where,}

$\mathrm{dC} / \mathrm{dt}=$ the rate of change of dye concentration with a change of reaction time.

$\mathrm{k}=$ the rate constant $\min ^{-1}$ and $\mathrm{C}$ is the concentration of dye at time $t$.

Then the integration of equation (2) between $\mathrm{t}=0$ and $\mathrm{t}=$ t gives;

$\ln \frac{\left[\mathrm{C}_{0}\right]}{[\mathrm{C}]}=\mathrm{Kt}$

Where: $\mathrm{C}_{0}=$ Initial dye concentration at time $\mathrm{t}=0$.

$\mathrm{C}=$ Dye concentration at time $\mathrm{t}$.

$\mathrm{k}=$ First order rate constant $\min ^{-1}$.

$\mathrm{t}=$ Reaction time in minutes.

\section{4- Energy Requirement}

The advanced oxidation treatment is directly affected by operation cost. To compare of reaction efficiencies that used parameter known as EE/O (electrical energy required to remove a pollutant by one order in one $\mathrm{m}^{3}$ of water or wastewater). EE/O calculated the electrical efficiency of an advanced oxidation process and allows for the comparison of various AOP methods. It is very required not only for several of AOPs also for economic analysis and comparison with conventional treatment. EE/O values are shown in equation 4 [20] [21].

$E E / O=\frac{P(K W) \times t(\min .) \times 1000}{V(L) X 60 \log \left(\frac{C o}{C}\right)}$

Where: $\mathrm{P}=$ the power input to the system such as UVlamp, generator of ozone, magnetic stirrer and water pump in $\mathrm{kW}$.

$\mathrm{t}=$ the reaction time in $\min$.

$\mathrm{V}=$ the volume of the wastewater in $\mathrm{L}$.

$\mathrm{C}_{0}=$ the initial concentration of pollutant water at $\mathrm{t}=0$.

$\mathrm{C}=$ the final concentration of pollutant water after treatment.

\section{5- Results and Discussion}

The decolorization rate of dye depends on the optimum $\mathrm{H}_{2} \mathrm{O}_{2}$ concentration to generate the hydroxyl radicals that destroy the organic polluted [22].
The catalyst is also affected by advanced oxidation processes [23]. In the presence of photocatalyst $\left(\mathrm{TiO}_{2}\right)$, $\mathrm{H}_{2} \mathrm{O}_{2}$ or only $\mathrm{H}_{2} \mathrm{O}_{2}$, the $\mathrm{pH}$ is an optimizing parameter at acidic that got accelerated the rate of decolorization. On the other hand, an increase in irradiation time led to greater decolorization rate[24].

According to a previous studies, a pre-study was conducted to find the optimum conditions of $\mathrm{H}_{2} \mathrm{O}_{2}$ concentration, $\mathrm{TiO}_{2}$ amount, $\mathrm{pH}$ and dye concentration and it was found that $\left[\mathrm{H}_{2} \mathrm{O}_{2}\right]=500 \mathrm{ppm},\left[\mathrm{TiO}_{2}\right]=100 \mathrm{ppm}$, $\mathrm{pH}=3$ and dye concentration $=15 \mathrm{ppm}$. Fig. 3, Fig. 4, Fig. 5 and Fig. 6 show the results of a continuous process for the four processes $\left(\mathrm{H}_{2} \mathrm{O}_{2} / \mathrm{UV}, \quad \mathrm{H}_{2} \mathrm{O}_{2} /\right.$ sunlight, $\mathrm{H}_{2} \mathrm{O}_{2} / \mathrm{TiO}_{2} / \mathrm{UV}$, and $\mathrm{H}_{2} \mathrm{O}_{2} / \mathrm{TiO}_{2} /$ sunlight) respectively at the optimum conditions. The flow rate to the reactor was adjusted according to the detention time $\mathrm{dt}=\mathrm{V} / \mathrm{Q}$ (volume/flow rate) [25]. When the flow rate increases (10, 30 and 60$) \mathrm{ml} / \mathrm{min}$ the detention time $(\mathrm{min})$ will be $(150$, 50 and 25) respectively. At each detention time, the same volume of wastewater had been treated but with different removal efficiencies. The treated volume is $1500 \mathrm{ml}$. The removal efficiency for four processes was $(84.65 \%$, $80.47 \%, 77.51 \%$, and $89.42 \%$ ) at the flow rate $10 \mathrm{ml} / \mathrm{min}$ and $(68.26 \%, 65.19 \%, 56.89 \%, 70.22 \%)$ at $60 \mathrm{ml} / \mathrm{min}$ respectively. Increasing the flow rate the UV lamp or sunlight will be submerged in shorter time, therefore, decreases the amount of provided power for $\mathrm{H}_{2} \mathrm{O}_{2}$ to generate more hydroxyl radical.

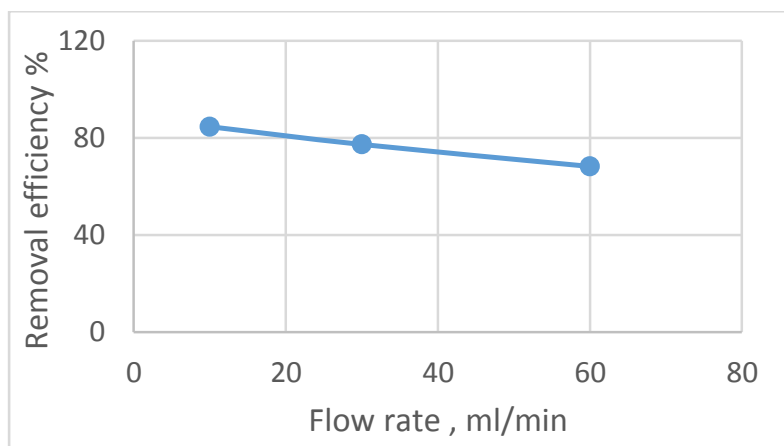

Fig. 3. Effect of Flow rate on the decolorization of red dye: $\mathrm{pH}=3,\left[\mathrm{H}_{2} \mathrm{O}_{2}\right]=500 \mathrm{mg} / 1$, [dye $]=15 \mathrm{mg} / 1$, and $2 \mathrm{UV}$ lamp

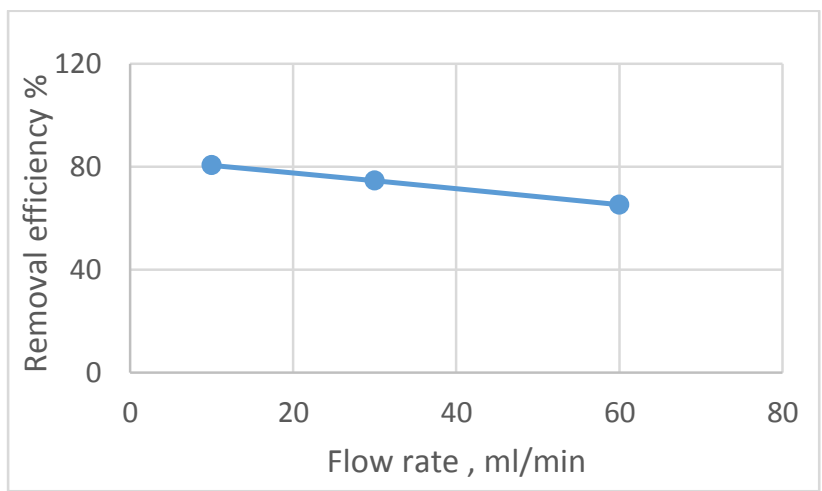

Fig. 4. Effect of Flow rate on the decolorization of red dye: $\mathrm{pH}=3,\left[\mathrm{H}_{2} \mathrm{O}_{2}\right]=500 \mathrm{mg} / \mathrm{l}$, $[$ dye $]=15 \mathrm{mg} / \mathrm{l}$, and Sunlight 


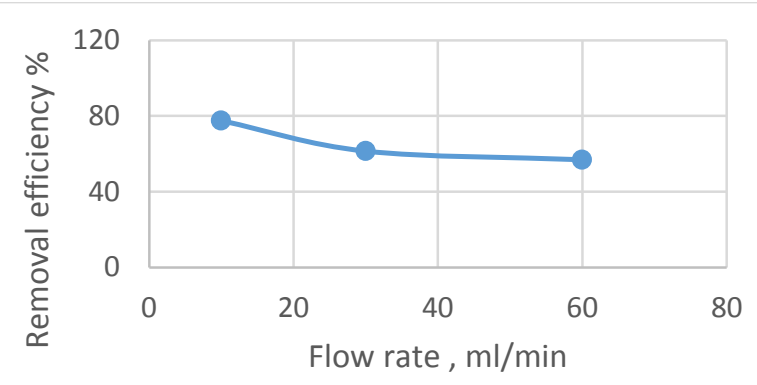

Fig. 5. Effect of Flow rate on the decolorization of red dye: $\mathrm{pH}=3,\left[\mathrm{H}_{2} \mathrm{O}_{2}\right]=500 \mathrm{mg} / \mathrm{l}$, [dye $]=15 \mathrm{mg} / 1,\left[\mathrm{TiO}_{2}\right]=$ $100 \mathrm{mg} / \mathrm{l}$ and $2 \mathrm{UV}$ lamp

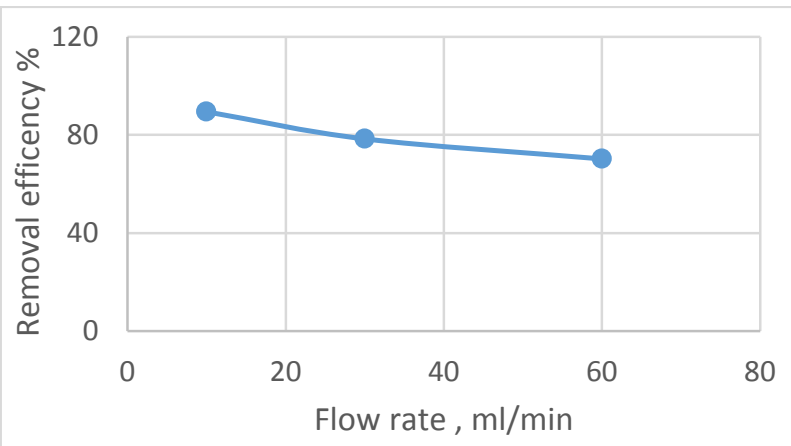

Fig. 6. Effect of Flow rate on the decolorization of red dye: $\mathrm{pH}=3,\left[\mathrm{H}_{2} \mathrm{O}_{2}\right]=500 \mathrm{mg} / \mathrm{l}$, [dye $]=15 \mathrm{mg} / 1,\left[\mathrm{TiO}_{2}\right]=$ $100 \mathrm{mg} / \mathrm{l}$ and Sunlight

\section{6- Kinetics Study}

The various values of reaction rate constant $\mathrm{k}\left(\mathrm{min}^{-1}\right)$ calculated from Eq. 3 are shown in Table $\mathbf{1}$ for different advanced oxidation processes.

For different $\left(\mathrm{H}_{2} \mathrm{O}_{2} /\right.$ sunlight, $\mathrm{H}_{2} \mathrm{O}_{2} / \mathrm{UV}, \mathrm{H}_{2} \mathrm{O}_{2} / \mathrm{TiO}_{2} / \mathrm{UV}$, and $\mathrm{H}_{2} \mathrm{O}_{2} / \mathrm{TiO}_{2} /$ sunlight) methods the $\mathrm{k}$ values were $0.0041 / \mathrm{min}, 0.0053 / \mathrm{min}, 0.0053 / \mathrm{min}$ and $0.0080 / \mathrm{min}$ respectively.

The coefficient of correlation is presented by $\mathrm{R}^{2}$ and explains the fitting extent of the equation, experimental information.

The values of those $\mathrm{R}^{2}$ are nearly closed or higher than 0.9 in all cases. It is apparent that $\mathrm{H}_{2} \mathrm{O}_{2} / \mathrm{UV}$ is better than $\mathrm{H}_{2} \mathrm{O}_{2}$ /sunlight process.

This means that the UV lamp is much faster than sunlight for photolysis of hydrogen peroxide. In the photocatalyst the addition of $\mathrm{H}_{2} \mathrm{O}_{2}$ ensures many formations of $\mathrm{OH}^{*}$ radicals that can be destroyed organic pollutants, the results showed that $\mathrm{H}_{2} \mathrm{O}_{2} / \mathrm{TiO}_{2}$ /sunlight is better than $\mathrm{H}_{2} \mathrm{O}_{2} / \mathrm{TiO}_{2} / \mathrm{UV}$ because sunlight contains a wavelength around $380 \mathrm{~nm}$ that catalyst $\mathrm{TiO}_{2}$ can be absorption this agrees with [26].

In the four advanced oxidation experiments, the kinetics model of red dye is represented as first-order reaction kinetics.

Table 1. The first-order reaction kinetics model for different advanced oxidation processes

\begin{tabular}{lll}
\hline Methods & $\mathrm{K}\left(\mathrm{min}^{-1}\right)$ & $\mathrm{R}^{2}$ \\
\hline $\mathrm{H}_{2} \mathrm{O}_{2} / \mathrm{UV}$ & 0.0053 & 0.9174 \\
$\mathrm{H}_{2} \mathrm{O}_{2} /$ sunlight & 0.0041 & 0.8635 \\
$\mathrm{H}_{2} \mathrm{O}_{2} / \mathrm{TiO}_{2} / \mathrm{UV}$ & 0.0053 & 0.9992 \\
$\mathrm{H}_{2} \mathrm{O}_{2} / \mathrm{TiO}_{2} /$ sunlight & 0.0080 & 0.9863 \\
\hline
\end{tabular}

\section{7- Calculation of Electrical Energy Requirements}

The advanced oxidation processes are required to spend energy for operating the equipment. In this study consist of four processes $\left(\mathrm{H}_{2} \mathrm{O}_{2} /\right.$ sunlight, $\mathrm{H}_{2} \mathrm{O}_{2} / \mathrm{UV}, \mathrm{H}_{2} \mathrm{O}_{2} / \mathrm{TiO}_{2} /$ $\mathrm{UV}$, and $\mathrm{H}_{2} \mathrm{O}_{2} / \mathrm{TiO}_{2}$ /sunlight) which is used a variable source of power like UV lamp and water pump. EE/O is the electrical energy per order of water or polluted water removal.

In the other hand, it means a powerful parameter and a measure of the degradation rates obtained in a very constant volume of wastewater as a function of the applied specific energy [20] [27].

Table 2 shows the comparison of energy requirements by various methods for the decolorization rate of brilliant reactive red dye at different flow rate dye. The energy required can be calculated from Eq. 4.

The results are apparent that the $\mathrm{H}_{2} \mathrm{O}_{2} / \mathrm{UV}$ and $\mathrm{H}_{2} \mathrm{O}_{2} / \mathrm{TiO}_{2} /$ sunlight processes most effective option of energy required and decolorization of dye.

Energy consumption of the advanced oxidation treatment increase with an increased in initial dye concentrations, flow rate and also with an increase in the applied dose [27].

Table 2. Comparison of the energy required by the different processes for the decolorization rate of brilliant reactive red dye at a different flow rate

\begin{tabular}{|c|c|c|c|c|c|c|}
\hline Reaction Conditions & \multicolumn{6}{|c|}{ Dye Conc. $=15 \mathrm{ppm}, \mathrm{H}_{2} \mathrm{O}_{2}=500 \mathrm{ppm}, \mathrm{TiO}_{2}=100 \mathrm{ppm}$ and $\mathrm{pH}=3$} \\
\hline Flow Rate & \multicolumn{2}{|c|}{$10(\mathrm{ml} / \mathrm{min})$} & \multicolumn{2}{|c|}{$30(\mathrm{ml} / \mathrm{min})$} & \multicolumn{2}{|c|}{$60(\mathrm{ml} / \mathrm{min})$} \\
\hline Methods of AOPS & $\begin{array}{l}\text { Declorization } \\
\text { rate } \%\end{array}$ & $\mathrm{EE} / \mathrm{O}\left(\mathrm{kWh} / \mathrm{m}^{3}\right)$ & $\begin{array}{c}\text { Declorization rate } \\
\%\end{array}$ & $\mathrm{EE} / \mathrm{O}\left(\mathrm{kWh} / \mathrm{m}^{3}\right)$ & $\begin{array}{c}\text { Declorization } \\
\text { rate } \%\end{array}$ & $\mathrm{EE} / \mathrm{O}\left(\mathrm{kWh} / \mathrm{m}^{3}\right)$ \\
\hline $\mathrm{H}_{2} \mathrm{O}_{2} / \mathrm{UV}$ & 84.65 & 12.62 & 77.34 & 15.94 & 68.26 & 20.61 \\
\hline $\mathrm{H}_{2} \mathrm{O}_{2} /$ Sunlight & 80.47 & 14.48 & 74.50 & 17.31 & 65.19 & 22.42 \\
\hline $\mathrm{H}_{2} \mathrm{O}_{2} / \mathrm{TiO}_{2} / \mathrm{UV}$ & 77.51 & 15.85 & 61.45 & 24.82 & 56.89 & 28.12 \\
\hline $\mathrm{H}_{2} \mathrm{O}_{2} / \mathrm{TiO}_{2} /$ Sunlight & 89.42 & 10.53 & 78.39 & 15.44 & 70.22 & 19.53 \\
\hline
\end{tabular}




\section{8- Conclusions}

Brilliant Reactive Red Dye can be removed in all of the advanced continuous methods of oxidation that is used in this study, at a flow rate range from (10-60) $\mathrm{ml} / \mathrm{min}$ and reaction time ranging from $(25-150) \mathrm{min}$. However, the increase in the flow rate led to a decrease in the decolorization rate. The higher decolorization was required longer reaction time to generate hydroxyl radical that can destroy the organic substance. The results show that the $\mathrm{H}_{2} \mathrm{O}_{2} / \mathrm{UV}$ and $\mathrm{H}_{2} \mathrm{O}_{2} / \mathrm{TiO}_{2} / \mathrm{UV}$ processes can be efficiently used for removal of textile wastewater because $\mathrm{H}_{2} \mathrm{O}_{2}$ absorb the light $<245 \mathrm{~nm}$ and $\mathrm{TiO}_{2}$ absorb the light $<$ $365 \mathrm{~nm}$. The maximum decolorization rate of dye may be achieved at acidic media $(\mathrm{pH}=3)$, a moderate concentration of $\mathrm{H}_{2} \mathrm{O}_{2}, 150$ min of UV irradiation and low flow rate by $10 \mathrm{ml} / \mathrm{min}$. The results indicated that sunlight is a suitable energy supply used in the photooxidation to remove organic substance due to its low cost and free availability.

\section{References}

[1] Y. M. Slokar, J. Zupan, and A. M. Le Marechal, "The use of artificial neural network (ANN) for modeling of the $\mathrm{H}_{2} \mathrm{O}_{2} / \mathrm{UV}$ decoloration process: part I," Dye. Pigment., vol. 42, no. 2, pp. 123-135, 1999.

[2] I. Koyuncu, "Reactive dye removal in dye/salt mixtures by nanofiltration membranes containing vinylsulphone dyes: effects of feed concentration and cross flow velocity," Desalination, vol. 143, no. 3, pp. 243-253, 2002.

[3] Y. M. Slokar and A. M. Le Marechal, "Methods of decoloration of textile wastewaters," Dye. Pigment., vol. 37, no. 4, pp. 335-356, 1998.

[4] S. K. Sharma, H. Bhunia, and P. K. Bajpai, "Photocatalytic decolorization kinetics and adsorption isotherms of a mixture of two anionic azo dyes: Reactive Red 120 and Reactive Black 5," Desalin. Water Treat., vol. 44, no. 1-3, pp. 261-268, 2012.

[5] A. Vogelpohl and S.-M. Kim, "Advanced oxidation processes (AOPs) in wastewater treatment," J. Ind. Eng. Chem., vol. 10, no. 1, pp. 33-40, 2004.

[6] T. Robinson, G. McMullan, R. Marchant, and P. Nigam, "Remediation of dyes in textile effluent: a critical review on current treatment technologies with a proposed alternative," Bioresour. Technol., vol. 77, no. 3, pp. 247-255, 2001.

[7] F. Zhang, J. Zhao, T. Shen, H. Hidaka, E. Pelizzetti, and N. Serpone, " $\mathrm{TiO}_{2}$-assisted photodegradation of dye pollutants II. Adsorption and degradation kinetics of eosin in $\mathrm{TiO}_{2}$ dispersions under visible light irradiation," Appl. Catal. B Environ., vol. 15, no. 1-2, pp. 147-156, 1998.

[8] Y. Yang and L. Xu, "Reusing hydrolyzed reactive dyebath for nylon and wool dyeing," Am. Dyest. Report., vol. 85, no. 3, pp. 27-34, 1996.

[9] H.-Y. Shu and C.-R. Huang, "Ultraviolet enhanced oxidation for color removal of azo dye wastewater," Am. Dyest. Report., vol. 84, no. 8, pp. 30-35, 1995.
[10] D. P. Mohapatra, S. K. Brar, R. D. Tyagi, P. Picard, and R. Y. Surampalli, "Analysis and advanced oxidation treatment of a persistent pharmaceutical compound in wastewater and wastewater sludgecarbamazepine," Sci. Total Environ., vol. 470, pp. 5875, 2014.

[11] I. K. Konstantinou and T. A. Albanis, " $\mathrm{TiO}_{2}-$ assisted photocatalytic degradation of azo dyes in aqueous solution: kinetic and mechanistic investigations: a review," Appl. Catal. B Environ., vol. 49, no. 1, pp. 1-14, 2004.

[12] M. Stylidi, D. I. Kondarides, and X. E. Verykios, "Pathways of solar light-induced photocatalytic degradation of azo dyes in aqueous $\mathrm{TiO}_{2}$ suspensions," Appl. Catal. B Environ., vol. 40, no. 4, pp. 271-286, 2003.

[13] S. Chakrabarti and B. K. Dutta, "Photocatalytic degradation of model textile dyes in wastewater using $\mathrm{ZnO}$ as semiconductor catalyst," J. Hazard. Mater., vol. 112, no. 3, pp. 269-278, 2004.

[14] M. Huang, C. Xu, Z. Wu, Y. Huang, J. Lin, and J. Wu, "Photocatalytic discolorization of methyl orange solution by Pt modified $\mathrm{TiO} 2$ loaded on natural zeolite," Dye. Pigment., vol. 77, no. 2, pp. 327-334, 2008.

[15] Y. Zhiyong et al., "Photocatalytic discoloration of Methyl Orange on innovative parylene- $\mathrm{TiO}_{2}$ flexible thin films under simulated sunlight," Appl. Catal. B Environ., vol. 79, no. 1, pp. 63-71, 2008.

[16] S. Senthilkumaar, K. Porkodi, and R. Vidyalakshmi, "Photodegradation of a textile dye catalyzed by sol-gel derived nanocrystalline tio 2 via ultrasonic irradiation," J. Photochem. Photobiol. A Chem., vol. 170, no. 3, pp. 225-232, 2005.

[17] W. Khan, I. Najeeb, and S. Ishtiaque, "Photocatalytic degradation of a real textile wastewater using titanium dioxide, zinc oxide and hydrogen peroxide," Int J Eng Sci, vol. 5, no. 7, pp. $\underline{61-70,2016 .}$

[18] Ali abd al hassan, 2017, "Treatment of produced water by Advanced Oxidation Processes", M.SC., Thesis, Al-Nahrain University College of Engineering

[19] U. Bali, E. Catalkaya, and F. Şengül, "Photodegradation of Reactive Black 5, Direct Red 28 and Direct Yellow 12 using UV, UV/H2O2 and UV/H2O2/Fe2+: a comparative study," J. Hazard. Mater., vol. 114, no. 1-3, pp. 159-166, 2004.

[20] A. Yasar, N. Ahmad, and A. A. A. Khan, "Energy requirement of ultraviolet and AOPs for the post-treatment of treated combined industrial effluent," Color. Technol., vol. 122, no. 4, pp. 201206, 2006.

[21] N. Azbar, T. Yonar, and K. Kestioglu, "Comparison of various advanced oxidation processes and chemical treatment methods for COD and color removal from a polyester and acetate fiber dyeing effluent," Chemosphere, vol. 55, no. 1, pp. 35-43, $\underline{2004 .}$ 
[22] C. M. So, M. Y. Cheng, J. C. Yu, and P. K. Wong, "Degradation of azo dye Procion Red MX-5B by photocatalytic oxidation," Chemosphere, vol. 46, no. 6, pp. 905-912, 2002.

[23] N. M. Mahmoodi, M. Arami, N. Y. Limaee, K. Gharanjig, and F. D. Ardejani, "Decolorization and mineralization of textile dyes at solution bulk by heterogeneous nanophotocatalysis using immobilized nanoparticles of titanium dioxide," Colloids Surfaces A Physicochem. Eng. Asp., vol. 290, no. 1-3, pp. 125$131,2006$.

[24] I. Ahmad Bhatti and S. Irshad, "UV Radiations Assisted Advanced Oxidation Approach for the Degradation of Reactive Azo Dye, Using $\mathrm{TiO}_{2}$ Photocatalyst.," J. Chem. Soc. Pakistan, vol. 39, no. 5, $\underline{2017 .}$
[25] J. C. Crittenden, R. R. Trussell, D. W. Hand, K. J. Howe, and G. Tchobanoglous, MWH's water treatment: principles and design. John Wiley \& Sons, 2012.

[26] I. A. Alaton and I. A. Balcioglu, "Photochemical and heterogeneous photocatalytic degradation of waste vinylsulphone dyes: a case study with hydrolyzed Reactive Black 5," J. Photochem. Photobiol. A Chem., vol. 141, no. 2-3, pp. 247-254, 2001.

[27] J. R. Bolton, K. G. Bircher, W. Tumas, and C. A. Tolman, "Figures-of-merit for the technical development and application of advanced oxidation processes," J. Adv. Oxid. Technol., vol. 1, no. 1, pp. $\underline{13-17,1996 .}$

\section{دراسة افضل ظروف باستخدام مفاعل مستمر لعملية الاكسدة المتقدمة لإزالة الصبغة الحمراء التقاعلية}

الخلاصة

تستخدم azo صبغة تفاعلية ذات اللون الاحمر والطول الموجي 534 نانومتر على نطاق واسع لصباغة

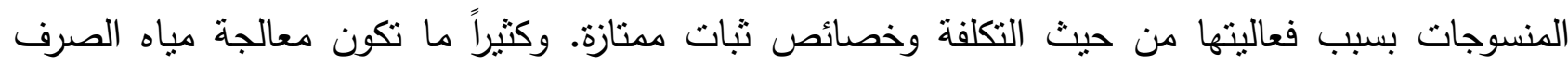
الصحي المحتوية على هذه الصبغة بالطرق التقليدية غير كافية بسبب مقاومتها للتنهور البيولوجي والكيميائي. في هذه الدراسة يتم استخدام مفاعل مستمر للعملية أكسدة متقدمة تقوم على استخدام ( ) لازالة الصبغة الحمراء.وتم أخذ افضل الظروف من حيث الاس للهيدروجيني ، تركيز بيروكسيد الهيدروجين، تركيز ثنائي اوكسيد التيتانيوم وتركيز الصبغة من

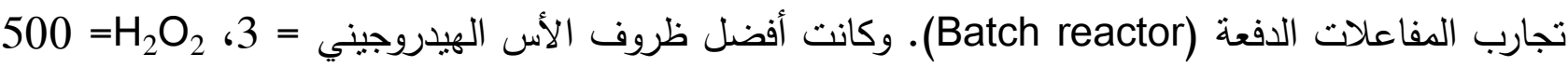
ملغامل, $100=\mathrm{TiO}_{2}$ ملغامل و تركيز الصبغ = 15ملغامل ـ تحت أفضل الظروف تمت إزالة اللون

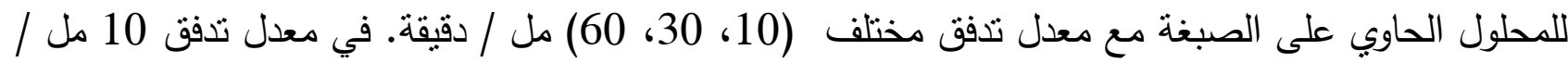

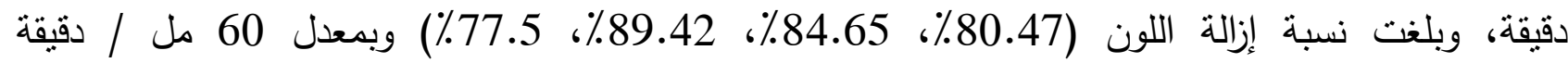

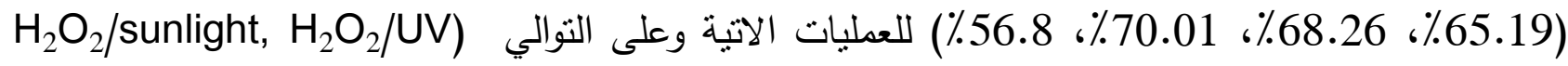
. $\left(\mathrm{H}_{2} \mathrm{O}_{2} / \mathrm{TiO}_{2} /\right.$ sunlight, $\mathrm{H}_{2} \mathrm{O}_{2} / \mathrm{TiO}_{2} / \mathrm{UV}$ 